\title{
Past as Prologue? The Risk of Adoption of Chemical and Biological Weapons by Non-State Actors in the EU
}

\author{
James REVILL*
}

\begin{abstract}
There have been relatively few serious incidents of chemical or biological terrorism in Europe; however, there is growing concern over how non-state groups might exploit chemistry and biology for hostile purposes in the future. This article uses the historical record of past incidents of chemical and biological weapons $(C B W)$ adoption by non-state actors to inform understandings of the current and future risks. To achieve this, the article analyses six interlinked clusters of factors that can be seen as important in assessing the risk of whether or not to adopt such weapons. These are: the perceived relative advantage of $C B W$ and their utilities; the complexity of such weapons; their ideological compatibility; the role of organisational structures; the visibility and 'fashionability' of such weapons; and the wider environmental context. Drawing from past cases of CBW adoption and the present European context, an analysis of these factors suggests that sophisticated CBW with gigantic effect are possible, but unlikely; however, the adoption and use of scruffy low-level chemical weapons is a distinct possibility. Accordingly, European public health agencies need to prepare for the possibility of a variety of $C B W$, not all of which are likely to be weapons of "mass destruction".
\end{abstract}

\section{INTRODUCTION}

Speaking at the 53rd Munich Security Conference, early in 2017, Bill Gates remarked that:

... the next epidemic could originate on the computer screen of a terrorist intent on using genetic engineering to create a synthetic version of the smallpox virus ... or a super contagious and deadly strain of the flu... Whether it occurs by a quirk of nature or at the hand of a terrorist, epidemiologists say a fast-moving airborne pathogen could kill more than 30 million people in less than a year. ${ }^{1}$

The use of chemical or biological weapons by non-state actors is not a new issue, but it has become more significant for a number of European states over the course of the last year. For example, Sweden described chemical weapons use by non-state actors as a

\footnotetext{
* The author would like to thank Julian Perry Robinson and Caitríona McLeish of the Harvard Sussex Program and Hylke Dijkstra and Anniek de Ruijter for their comments on, and discussions around, earlier drafts of this paper. Thanks too go to Gary Ackerman and Markus Binder for additional insights pertaining to CB incidents; and Jeremy Littlewood for early conceptual conversations around this topic. The author would also like to thank the anonymous reviewer for their comments and suggestions which have also helped strengthen the paper. This work was supported by the Economic and Social Research Council grant ES/L014505/1 on Data Capture of Syria Chemical Weapons Allegations; and Economic and Social Research Council grant ES/K011324/1 on Strategic Governance of Science and Technology Pathways to Security. Data citation is included in the references and the body text of the paper.

1 B Gates, "Speech by Bill Gates at the 53rd Munich Security Conference", 53rd Munich Security Conference (Munich Security Conference Foundation, 2017).
} 
"grave risk and a major concern"; 2 Germany declared the "danger of a use of biological agents as a weapon, in particular by terrorist groups, is to be taken seriously"; 3 and, indeed, the EU has expressed "grave concern" "about the risk of non-State actors acquiring and using toxic chemicals". 4

There are reasonable grounds for such concern, biology is getting relatively easier, more accessible and ever more powerful; whereas chemical weapons in the hands of non-state actors in Syria and Iraq is a regrettable reality. Yet gloomy predictions of apocalyptic chemical and biological weapons (CBW) in the hands of non-state actors rather ignores a complex set of factors that feed into decisions to adopt - or reject - such weapons, yet alone use them.

This article is part of a special issue that analyses the interactions between public health and security policy in Europe. The article seeks to explore what the past can tell us about the future risk of chemical and biological weapons adoption by non-state actors with a particular focus on the risks to Europe. In doing so, it challenges some of the bolder claims pertaining to an imminent darker chemical and biological weapons future. It does this by exploring different factors that are likely to feed into the calculus of whether or not such weapons will be adopted and/or used by non-state actors in the European context, including the relative advantage of $\mathrm{CBW}$, the complexity of such weapons, the ideological compatibility, organisational factors, the visibility of such weapons and the wider European environmental context.

An exploration of these key factors suggests that, contrary to more alarmist claims, the seductive appeal of CBW with gigantic effect is likely to remain an unobtainable mirage for the short-term. However, as the synthesis of the factors addressed in this article shows, small groups of non-state actors with operationally relevant expertise are already able to launch crude, low-level, scruffy and opportunistic chemical weapons attacks, and this may be refined in the future. This suggests that public health preparations in Europe need to be able deal with a spectrum of CBW risks.

The paper begins with a discussion around the literature on technology adoption before laying out a framework orientated around six clusters of factors. The paper then proceeds by outlining the limits of using the past as prologue for understanding contemporary risks. The clusters of factors are then explored in turn using the available empirical data pertaining to past cases of CBW adoption and taking into account the evolving opportunities and challenges of the European context. The paper concludes with some reflections on what the past suggests about the future of CBW adoption in the European context.

\section{FramewORK FOR THE ADOPTION OF CBW BY NON-STATE ACTORS}

The use of the term "adoption" is intended to denote the choice of a non-state actor to pursue chemical or biological weapons with a view to the assimilation of such weapons.

2 Sweden, "Statement at the 84th Session of the Executive Council", Eighty-Fourth Session of the Executive Council of the Organisation for the Prohibition of Chemical Weapons (OPCW, 2017).

3 Germany, "General Statement", Eighth Review Conference of the States Parties to the BTWC (UN Office in Geneva 2016).

4 Malta on Behalf of the EU, "Statement on Behalf Of The European Union Delivered by H.E. Ambassador Joseph Cole Permanent Representative of The Republic of Malta", 84th Session Of The Executive Council of the OPCW (OPCW, 2017). 
This remains a significant part of the process of innovation, ${ }^{5}$ as Michael Horowitz notes, a "key puzzle is how terrorist groups decide whether to adopt the innovation". 6

To explore this question, this article develops a framework for analysis of CBW adoption by non-state actors. The framework is not proposed as a perfect typology of factors that influence non-state adoption, nor are the clusters of factors neatly delineated, isolated groupings that can be dealt with in an equal manner. On the contrary, these factors overlap and interact with each other, with some of greater salience than others. Nonetheless, such a framework provides a means of trying to tease out different issues to consider in seeking to understand the risk of CBW adoption by non-state actors in the European context, as the summary in Figure 1 below illustrates. Moreover, it does so by building on established frameworks for thinking about adoption, specifically Roger's five-factoral framework for the adoption of (peaceful) technologies, ${ }^{7}$ combined with further insights from terrorism and security scholarship including the work of, inter alia, Crenshaw, ${ }^{8}$ Ackerman, ${ }^{9}$ Jackson ${ }^{10}$ Rasmussen, ${ }^{11}$ Bale and Dolnik. ${ }^{12}$

In employing this framework, this article eschews a technologically deterministic approach to looking at CBW adoption, in favour of a more constructivist approach that recognises the significance of multiple social factors in shaping technology and innovation. This is important as an antidote to more technologically deterministic approaches that erroneously assume "innovation necessarily entails the widespread diffusion of new technologies or techniques across terrorist organizations", ${ }^{13}$ when this is not the case. ${ }^{14}$

It also seeks to draw from history whilst recognising that histories of CBW adoption by non-state actors have their limitations: in part, because of the assumptions, interpretations and definitions for example over what constitutes $\mathrm{CBW}$; in part, because of considerable missing information on inter alia the perpetrators, the agents used, the motivations and indeed the validity of some reported cases; ${ }^{15}$ and, in part, because there exist several cases in which non-events or naturally occurring phenomenon have been mistaken for - or deliberately misrepresented as - chemical and biological weapons use. ${ }^{16}$ Such non-cases

5 A Dolnik, Understanding Terrorist Innovation: Technology, Tactics and Global Trends (Routledge, 2009) and M Crenshaw, "An Organizational Approach to the Analysis of Political Terrorism" (1985) 29 Orbis 465.

6 MC Horowitz, "Nonstate Actors and the Diffusion of Innovations: The Case of Suicide Terrorism" (2010) 64(4) International Organization 33.

7 EM Rogers, "Diffusion of Preventive Innovations" (2002) 27 Addictive Behaviors 989, available at <http://www. ncbi.nlm.nih.gov/pubmed/12369480>.

8 Crenshaw, supra, note 5.

9 GA Ackerman and LE Pinson, "An Army of One: Assessing CBRN Pursuit and Use by Lone Wolves and Autonomous Cells" (2014) 26 Terrorism and Political Violence 226, available at <http://www.tandfonline.com/doi/ abs/10.1080/09546553.2014.849945>.

10 BA Jackson and DR Frelinger, "Rifling through the Terrorists' Arsenal: Exploring Groups' Weapon Choices and Technology Strategies" (2008) 31 Studies in Conflict \& Terrorism 583.

11 MJ Rasmussen, "Terrorist Innovations in Weapons of Mass Effect: Preconditions, Causes, and Predictive Indicators" (Workshop Report, August 2010), available at <http://calhoun.nps.edu/bitstream/handle/10945/25358/ 2010_019_Terrorist_WME.pdf?sequence $=1>$.

12 Dolnik, supra, note 5.

13 Rasmussen, supra, note $11,9$.

14 Horowitz, supra, note 6, 33-64.

15 J Perry Robinson, "Gaps and Lies in Information on the Ghouta Event" Harvard Sussex Program, Syria Workshop Paper (March 2016).

16 See for example J Robinson, J Guillemin and M Meselson, "Yellow Rain: The Story Collapses" (2016) 68 Foreign Policy 100; E Geissler and RH Sprinkle, "Disinformation Squared" (2013) 32 Politics and the Life Sciences 2; 
The relative advantage of CBW is not just in mass killing, but can also be derived from other possible utilities, such as sabotage, media attention and

Relative advantage

Complexity compatibility

Organisational

Compatibility disruption. Some CBW utilities can be augmented by sensationalist reporting of threats leading to a disproportionate response. However, there are also disadvantages to CBW adoption, including the opportunity costs of pursuing this method of causing harm, the potential for alienating possible constituencies and the risk of backlash.

Biology may be getting easier, but it remains relatively complex to achieve weapons with significant effect. Similarly, strategic chemical weapons will be highly complex; however, crude, scruffy chemical weapons are clearly within the means of some radical groups and may be refined in the future.

The frequently invisible, intangible, insipid and indiscriminate nature of CBW and the manner through which they cause harm (through the contamination and destruction of the body from within), has fed into what some see as a "taboo" surrounding CBW, both of which remain subject to special constraints. However, the obloquy chemical weapons is vulnerable to being eroded through the adoption and persistent use of scruffy, improvised chemical weapons.

The decentralisation of some extremist movements raises the possibility of a larger number of smaller-scale attacks, including attacks potentially using low-level or scruffy chemical weapons. However, decentralisation is likely to work against significant mass destructive CBW programs, which will probably require the centralisation of resources.

Biological weapons and strategic chemical weapons continue to lack

Visibility significant visibility. However, low-level chemical weapons have (fashionability) undoubtedly become more visible, to the extent that they could become grimly fashionable amongst certain groups.

Whilst windows of opportunity to acquire certain dual-use chemicals for hostile use remain, the storage of dual-use agents is comparatively well Environmental regulated across Europe, with the environment less conducive to the acquisition and testing of $\mathrm{CBW}$ without detection. Moreover, response and context resilience in the European context is comparatively more advanced, although European public health preparedness can neither be neglected nor fixated on a particular form of CBW threat.

Figure 1. Summary of factors identified as significant in CBW adoption 
persist perhaps because of the power of $\mathrm{CBW}$ allegations in propaganda and the demonisation of adversaries; as Robinson has remarked "Accusations of association with $[\mathrm{CBW}]$ have for centuries ... been used by well-intentioned as well as unscrupulous people to vilify enemies and to calumniate rivals". 17

The point is that the past record of CBW needs to be treated with caution because it is potentially incomplete, inconsistent and contaminated with politics and uncertainty. Nevertheless, it cannot be ignored by those seeking to make sense of the future risk of CBW adoption by non-state groups and, whilst such factors cannot be used to predict specific changes in the adoption of CBW, there are perhaps some generalisable lessons that may be learned from the past that can inform the development of a framework for thinking about CBW adoption in the future.

\section{Relative advantage and utilities}

The first factor is the perceived relative advantage of chemical or biological weapons over other means of causing harm. As Rogers points out, "[d]iffusion scholars have found [the] relative advantage to be one of the best predictors of an innovation's rate of adoption"; ${ }^{18}$ moreover, several scholars of terrorist innovation have referred to the importance of the relative advantage factor. ${ }^{19}$

\begin{tabular}{|c|c|c|}
\hline \multicolumn{2}{|c|}{ Utility } & Example \\
\hline Economic & - Animal rights activists claimed to contaminate Lucozade (UK, 1991) \\
sabotage & - Poisoning of Sri Lanka tea crops by the LTTE (Sri Lanka, 1983) $)^{21}$ \\
\hline Media & - Mau Mau poisoning of livestock (Kenya, 1954) \\
attention and & - Animal rights activities media attention to animal testing (UK, 1991) $)^{24}$ \\
prestige & - Larry Wayne Harris alerting Americans to the BW threat (US, 1995) ${ }^{25}$ \\
\hline
\end{tabular}

Figure 2. Utilities of CBW and illustrative example cases.

(F'note continued)

M Leitenberg, RA Zilinskas and JH Kuhn, The Soviet Biological Weapons Program: A History (Harvard University Press, 2012) 411; M Leitenberg, "China's False Allegations of the Use of Biological Weapons by the United States during the Korean War” (Cold War International History Project, Working Paper 78, 2016) 78.

17 JPP Robinson, "Alleged Use of Chemical Weapons in Syria", Harvard Sussex Program Occasional Paper 4 (26 June 2013), available at <http://www.sussex.ac.uk/Units/spru/hsp/occasional papers/HSPOP_4.pdf>.

18 EM Rogers, "Attributes of Innovations and Their Rate of Adoption" in EM Rogers, Diffusion of Innovations, 4th edn (The Free Press, 1995) 216.

19 G Ackerman, 'Appendix III: Understanding Terrorist Innovation through the Broader Innovation Context' in Rasmussen, supra, note 11.

20 US Dept of Justice, "Report to Congress on the Extent and Effects of Domestic and International Terrorism on Animal Enterprises" (1993) 27.

21 WS Carus, "Bioterrorism and Biocrimes: The Illicit Use of Biological Agents Since 1900" (Centre for Counterproloferation Research, National Defense University, Washington DC, February 2001 Revision).

22 Carus, supra, note 21.

23 A Welch, "Iraq - The Evolution of the IED" (2008) Autumn CBRNe World 12.

24 Supra, note 20.

25 J Tucker (ed.), Toxic Terror: Assessing Terrorist Use of Chemical and Biological Weapons (MIT Press, 2000) 250. 


\begin{tabular}{|c|c|}
\hline Incapacitation & $\begin{array}{l}\text { - Rajneesh use of salmonella to incapacitate voters (Oregon, US, 1984) } \\
\text { - The Weather Underground efforts to incapacitate (US, 1970) } \\
\text { - Teargassing of Czech Gay Pride parade (Czech Republic, 2008) }{ }^{27}\end{array}$ \\
\hline $\begin{array}{l}\text { Criminal } \\
\text { purposes }\end{array}$ & $\begin{array}{l}\text { - Kuntal Patel poisoning her "controlling" mother in law (UK, 2014) } \\
\text { - Carol Anne Bond's chemical assault of love rival (US, 2006) } \\
\text { - Spread of smallpox in Brazilian indigenous tribes (Brazil, 1957) }\end{array}$ \\
\hline $\begin{array}{l}\text { Destabilisation } \\
\text { and disruption }\end{array}$ & $\begin{array}{l}\text { - SNLA contaminated vodka mailing with caustic acid (UK, 2008) } \\
\text { - Aum Shinrikyo use of Sarin in the Tokyo subway (Japan, 1995) } \\
\text { - CSA efforts to hasten the apocalypse (US, 1986) }\end{array}$ \\
\hline Deter and deny & $\begin{array}{l}\text { - "Pro-life" maloderant attacks on abortion clinics (Florida, 1998) } \\
\text { - Release of sewer water onto Palestinian land? (Khadder, 1997) } \\
\text { - Threatened release of chlorine by Muslim forces? (Tuzla, 1992) }\end{array}$ \\
\hline
\end{tabular}

Figure 2. (Continued.)

Yet in order to appreciate the relative advantage, it requires an understanding of the utilities of CBW. As noted elsewhere "[n]ot all CBW are Weapons of Mass Destruction and to think otherwise is dangerous", ${ }^{37}$ nor is killing the only reason for the pursuit of such weapons. Rather CBW can serve a number of possible purposes from generating fear to stimulating media attention to economic sabotage and, indeed, there are examples where groups have eschewed highly-lethal CBW, such as in the case of the Rajneesh Cult, in part to avoid undue attention. Of course in some cases killing may be a key objective, but a focus on killing belies a number of other utilities CBW may be perceived as fulfilling, something outlined in Figure 2 above, which further illustrates both the long history and diversity of CBW adopters. The frequently sensationalised media coverage of $\mathrm{CBW}$ and the association of CBW with

26 JV Parachini, "The Weather Underground" in Tucker, supra, note 25, 43.

27 Trend News Agency, "Czech Republic's First Gay Pride Parade Attacked by Rightwingers" (2008) 15 Trend News Agency, available at <http://en.trend.az/world/other/1234372.html>.

28 "Woman Tried to Poison Mother in Plot Inspired by Breaking Bad, Court Told" The Guardian (2014).

29 C Doyle, "Bond v. United States: Validity and Construction of the Federal Chemical Weapons Statute", CRS report for Congress (2014) <https://fas.org/sgp/crs/nuke/R42968.pdf>.

30 Carus, supra, note 21.

31 "Poison Plotters Jailed" Manchester Evening News (12 January 2013), available at <http://www. manchestereveningnews.co.uk/news/greater-manchester-news/poison-plotters-jailed-941042>; see also D Ward, "Nationalist Denies Sending Caustic Soda through Post" The Guardian (8 January 2008).

32 AA Nehorayoff, B Ash and DS Smith, "Aum Shinrikyo's Nuclear and Chemical Weapons Development Efforts" (2016) 9(1) Journal of Strategic Security 35.

33 Tucker, supra, note 25, 250.

34 M Healy, "FBI Probing Acid Attacks at Abortion Clinics" Los Angeles Times (19 July 1998).

35 CNS, "Chronology of CBW Incidents Targeting Agriculture 1915-2008” (2008).

36 CIA Directorate of Intelligence, "Tuzla, Bosnia and Hercegovina: A Review of the Geographical Realities", Intelligence Memorandum. Office of Trade, Resources and Technology (7 July 1992).

37 J Revill, C McLeish and JP Robinson, "Case Study on Chemical and Biological Weapons", Project on Strategic Governance of Science and Technology (under review 2015). 
mass destruction, necessitates that in the event of an attack using these weapons, public reactions may well be disproportionate to the casualty-causing potential of such weapons.

Whilst CBW therefore have a number of utilities, some of which can be amplified through media hype - and public health actors need to prepare accordingly - it is also clear that there are other means of achieving the objectives of non-state groups. Gill et al have certainly argued that in the case of Hamas, "the fact that suicide bombings are cheaper, less likely to alienate their constituency and more cost-effective means that this particular manifestation of violence is far more elegant than a chemical attack..."; 38 whereas the Europol TE-SAT report for 2016 stated, "Terrorists prefer the use of conventional firearms and explosives because of their availability, simplicity and effectiveness". 39 Indeed, IEDs have been employed for sabotage, destabilisation, demoralisation, disruption, area-denial and deterrence and have been used widely in Europe; whereas marauding Mumbai-style attacks have been used to devastating effect in Norway and, more recently, France.

Moreover, CBW have relative disadvantages over other means of causing harm. As discussed below, CBW are complex and the pursuit of such weapons generates opportunity costs; they are frequently met with opprobrium, to the extent that the adoption and use of such weapons could alienate many otherwise sympathetic constituents and potentially generate a comparatively more robust response from states; and the acquisition, development and or testing of such weapons can leave groups vulnerable to detection, a risk which is particularly pronounced in the European environmental context.

This notion of relative advantage (and disadvantage) and multiple utilities of CBW weapons suggests a note of caution in fixating European policy on preventing the proliferation of new, high-tech chemical and biological weapons of mass destruction, particularly if such a policy is pursued at a cost to efforts to prevent pernicious CBW with effects short of mass destruction. Indeed, it suggests a need for the EU and the composite member states to guard against a spectrum of possible CBW health threats, ranging from the use of more high-tech forms of chemical and biological weapons with gigantic effect on humans, to localised opportunistic attacks, including attacks on agriculture, livestock and even material.

\section{Complexity}

The second factor is "the perceived complexity of the innovation in terms of adoption and use". 40 This is important in the innovation literature, as Rogers remarked, "[t]he complexity of an innovation, as perceived by members of a social system, is negatively related to its rate of adoption". ${ }^{41}$ Several scholars of terrorist innovation have also highlighted the issue of complexity; ${ }^{42}$ or, as Cragin et al have stated, "[h]ow simple or complex a technology appears affects perceptions of how risky it will be to adopt."43

38 P Gill and others, "Malevolent Creativity in Terrorist Organizations" (2013) 47 Journal of Creative Behavior 125.

39 Europol, TE-SAT 2016, "European Union Terrorism Situation and Trend Report 2016", doi:10.2813/525171; see also Gill, supra, note 38, 133.

40 Rasmussen, supra, note 11.

41 Rogers, supra, note 18, 242.

42 Dolnik, supra, note 5.

43 K Cragin and others, "Sharing the Dragon's Teeth Terrorist Groups and the Exchange of New Technologies" (RAND Corporation, 2007). 
In most cases terrorist groups appear to have largely opted for the simplest pathway towards the achievement of their goals and the weapons used tend to be vernacular, functional devices drawing on local and readily-available materials, rather than sophisticated, "baroque" technologies. This is certainly the case with IEDs, the history of which is characterised largely by incremental innovations - although nevertheless frequently effective ones - with many means of delivery recycled from the past. ${ }^{44}$ Complexity can therefore be seen as important in the adoption of technology by terrorists generally, but is perhaps particularly acute in the case of CBW technology.

Some CBW can be relatively simple: "chlorine-augmented, vehicle-borne IEDs," as employed by Al-Qaeda in Iraq (AQI) from 2006 to 2007 are not sophisticated weapons. $^{45}$ Attacks on chemical production facilities, an apparent tactic of Serbian forces in the early to mid-1990s, ${ }^{46}$ employed relatively simple technologies specifically explosives - with toxicity a secondary by-product. Direct contamination of food, ${ }^{47}$ drink $^{48}$ or healthcare products ${ }^{49}$ does not require particularly sophisticated technology for the purposes of delivery - although may require some considerable skill to culture and scale-up a biological agent - and has been a common approach in European CBW incidents. ${ }^{50}$ Similarly, the contamination of water systems, something familiar to Europe, ${ }^{51}$ can also be relatively easily attempted. However, in most cases such methods of dissemination have generated results that are far short of the "mass destruction" that CBW are associated with, although this does not mean such a possibility can be ignored by those working on public health preparedness.

Although some relatively simple approaches could cause significant harm, mass casualty attacks still require considerable expertise, something particularly acute in the context of biological weapons. ${ }^{52}$ The most effective route to weaponising biology is arguably through the process of aerosolising agents, something recognised mid-way through the last century as opening up the theoretical possibility of using biological weapons on a gigantic scale. ${ }^{53}$ However, realising such theoretical potential is difficult and it took states decades to develop

44 J Revill, Improvised Explosive Devices - The Paradigmatic Weapon of New Wars (Palgrave Macmillan, 2016).
45 Welch, supra, note 23, 12-13.
46 "From 1993 to 1995, for example, Serbian forces launched six attacks on a Petrochemia facility near Kutina, Croatia, that stored large quantities of anhydrous ammonia as well as a variety of other potentially hazardous chemicals; these attacks involved rockets, bombs, artillery, and mortars": T Karasik, Toxic Warfare (RAND Project Air Force, 2002).

47 See for example the cases of food poisoning reported, although not confirmed, H Mohtadi and A Murshid, "A Global Chronology of Incidents of Chemical, Biological, Radioactive and Nuclear Attacks: 1950-2005” (7 July 2006), available at <https://people.uwm.edu/mohtadi/files/2016/07/A-Global-Chronology-of-Incidents-of-ChemicalBiological-and-Radionuclear-Attacks.doc-1u8sbvu.pdf>.

48 Kuntal Patel poisoning her "controlling" mother in law via a soft drink, supra, note 28.

49 See for example the case of the Minesota Patriots in N Khardori, Potential Agents of Bioterrorism: Historical Perspective and an Overview (2006) and Carus, supra, note 21.

50 See for example: the 2014 Kuntal Patel case of Coke poisoning; the 1984 Rajneesh cult poisoning of salad bars; Steven Robinsons' contamination of Vladivar vodka in 2007; the Animal Liberation Front (ALF) plan to contaminate bottles of Lucozade in 1991; or the threatened - not undertaken - contamination of Coca-Cola and Nestlé products with hydrochloric acid by the Informal Anarchist Federation.

51 For example, in the 1960s the "Provos", the Dutch counter-culture revolutionaries, threatened to disseminate LSD in the Dutch water system: R Kempton, Provo: Amsterdam's Anarchist Revolt (New York, Autonomedia, 2007).

52 As much is explicitly recognised in Anders Breivik's manifesto, which suggests the use of anthrax requires "extensive practical knowledge, training, and highly advanced equipment".

53 Revill, Mcleish and Robinson, supra, note 27. 
more predictable biological weapons, ${ }^{54}$ and even then such weapons were acutely vulnerable to environmental factors. ${ }^{55}$ For non-state groups such complexity has proven a significant barrier to CBW development. By means of an example, one of the best-resourced biological weapons programs, that of Aum Shinrikyo, failed variously because the group acquired the wrong strain, contaminated fermenters and were faced with insurmountable production and dissemination difficulties. ${ }^{56}$ There are of course exceptions, such as the 2001 anthrax Letter Attacks in the US. However, if one accepts the conclusions of the FBI that this sophisticated attack with aerosolised anthrax in the US postal system was perpetrated by a US biodefence researcher, Dr Bruce Ivins, ${ }^{57}$ it is an exception that proves the rule.

To circumvent the difficulties with aerosolisation, arguably one could use human-tohuman transmissible biological agents as part of a suicide bioterror operation. There are good reasons for concern over how crude suicide bioterrorists could employ such a tactic. However, the use of highly contagious agents is also poorly predictable and would have to deal with social factors, such as the "spatial contact process among individuals", which can spell "out the difference between large-scale epidemics and abortive ones". 58

The counter to this argument is the growing access to data and the changing human geography of the life sciences. Some $83 \%$ of European households reportedly are online, effectively allowing access to what is a growing body of available data on CBW, including so-called bioterrorist "recipes" and "blueprints" that are available in both mainstream scientific as well as more subversive literatures online. It is also clear that there is a changing human geography in European life sciences (for peaceful purposes), with the emergence of 30 DIY-bio groups located in Europe ${ }^{59}$ and some 80 European teams in the international Genetically Engineered Machines (IGEM) competition in $2016 .^{60}$ This is compounded by reports that groups such as Daesh have deliberately sought to recruit foreign fighters "including some with degrees in physics, chemistry, and computer science, who experts believe have the ability to manufacture lethal weapons from raw substances". ${ }^{1}$

Whilst it would be unwise to ignore such developments, there is a need for caution in looking at the extent to which new technologies and geographies will facilitate the adoption of chemical and biological weapons by groups seeking to target European countries. First, data is not information, and information is not knowledge, let alone the tacit knowledge

\footnotetext{
54 SIPRI, The Prevention of CBW. The Problem of Chemical and Biological Warfare: Volume V(SIPRI, in association with Oxford University Press, 1971).

55 RD Kirby, The Sergeant: A Biological Missile (Eximdyne, 2014).

56 R Danzig and others, Aum Shinrikyo: Insights Into How Terrorists Develop Biological and Chemical Weapons, 2nd edn (Center for a New American Security, 2012), available at <http://www.cnas.org/files/documents/publications/ CNAS_AumShinrikyo_SecondEdition_English.pdf>; M Leitenberg, “Aum Shinrikyo's Efforts to Produce Biological Weapons: A Case Study in the Serial Propagation of Misinformation” (1999) 11 Terrorism and Political Violence 149.

57 This remains a controversial conclusion of the FBI investigation which remains unproved in a court of law as Ivins took his life before trial.

58 Derek Cummings Epstein, Shubha Chakravarty, Ramesh Singa, and Donald Burke J, Toward a Containment Strategy for Smallpox Bioterror: An Individual-Based Computational Approach (Brookings Institution Press, 2004).

59 In 2016, according to the DIY-bio website there are some 88 DIY bio groups, with 6 in Canada, 36 in the US, 6 in Latin America, 29 in Europe, 7 in Asia and 4 in Oceana. The DIYbio Google group has 4,665 members.

60305 teams registered with 300 remaining in the 2016 Internationally Genetic Engineering Machines competition.

61 Immenkamp, Beatrix. "ISIL/Da'esh and 'Non-Conventional' Weapons of Terror," 2015. <http://www.europarl. europa.eu/RegData/etudes/BRIE/2015/572806/EPRS_BRI(2015)572806_EN.pdf>.
} 
required for $\mathrm{CBW} .^{62}$ In many cases a degree of determination and dedication will be required merely to separate online fantasy from fact and identify operationally useful information (of relevance to the European context) from nonsense (or information pertinent to contexts other than Europe). Second, with new technologies there is the potential for such tools to enable some, but certainly not all, actors, and even then new technologies bring new challenges. CRISPR, gene editing technology is currently seen as a particular source of promise and peril, which purportedly enables "even largely untrained people to manipulate the very essence of life". 63 As much may be technically true, yet "untrained people" would nonetheless require some guidance in identifying suitable areas of genetic structures to manipulate. Moreover, CRISPR would only get aspiring weaponeers so far, with the process of culturing, scaling-up and weaponisation still requiring considerable attention and interdisciplinary skills, typically generated through "large interdisciplinary teams of scientists, engineers, and technicians", ${ }^{64}$ in order to be effective.

Indeed, for all the progress in science and technology, biological weapons are still not used, in part, because of the complexity of such weapons; and the chemical weapons that are used today are largely the same as the chemical weapons of 100 years ago. As Robinson noted "It remains the case today that, in the design of CBW, increasingly severe technological constraint sets in as the mass-destruction end of the spectrum is approached: the greater and more assured the area-effectiveness sought for the weapon, the greater the practical difficulties of achieving it". 65

Thus, although complexity is an important factor, it is not an argument for complacency. Rather it highlights the significance of, first, guarding against technological surprise, including the shock of the old and the scruffy; and, second, sensitising those with the potential skill-sets to contribute to serious programs to dual-use risks and engaging scientists in academic and industry. Past research has suggested there is a low-level of awareness of dual-use risks amongst academics working in the fields of chemistry and biology across Europe, ${ }^{66}$ and although there have since been a number of commendable initiatives to raise awareness and promote a culture of responsibility, including through the recent Hague Ethical Guidelines, ${ }^{67}$ it is unclear how widely promulgated or sustainable such initiatives have been.

\section{Ideology}

A third factor is the compatibility of $\mathrm{CBW}$ with the ideological outlook of non-state actors. Ideology matters to the extent it may pre-determine the possibility of

\footnotetext{
62 See K Vogel, "Bioweapons Proliferation: Where Science Studies and Public Policy Collide" (2006) 36 Social Studies of Science 659; J Revill and C Jefferson, "Tacit Knowledge and the Biological Weapons Regime" (2014) 41 Science and Public Policy 597.

63 DM Gerstein, "Can the Bioweapons Convention Survive Crispr?" (2016) Bulletin of the Atomic Scientists, 25 July 2016, available at http://thebulletin.org/can-bioweapons-convention-survive-crispr9679.

64 S Ben Ouagrham-Gormley, "Barriers to Bioweapons : Intangible Obstacles to Proliferation Barriers to Bioweapons" (2012) 36 International Security 80.

65 JP Robinson, "Near-Term Development of the Governance Regime for Biological and Chemical Weapons" (Science \& Technology Policy Research, University of Sussex, 2006).

66 See J Revill and others, "Biosecurity Education: Surveys from Europe and Japan", Inter Academy Panel Workshop on Promoting Education on Dual Use Issues in the Life Sciences (2009).

67 OPCW, "The Hague Ethical Guidelines" (2016), available at <https://www.opcw.org/fileadmin/OPCW/ Science_Technology/Hague_Ethical_Guidelines_Brochure.pdf $>$.
} 
adoption or not. ${ }^{68}$ As Ackerman has noted "[p]ractices that enjoy greater legitimacy, culturally or otherwise, in the wider social system are likely to diffuse more quickly than those that do not." ${ }^{\text {"69 }}$ Many means and methods of causing harm - from the crossbow to aerial bombardment to dumb-dumb bullets - have been subject to opprobrium. Yet unlike other such weapons where norms have eroded, chemical and biological weapons have largely continued to remain subject to a cross-cultural norm against their acquisition, development and use, to the extent some have described CBW as "taboo".70 Moreover, this is a norm which has been reinforced and codified through the development of an international governance regime comprising of treaties, such as the Chemical and Biological Weapons Conventions, and national laws that have been relatively well implemented across EU member states.

However, as history indicates, the norm against $\mathrm{CBW}$ is not inviolable; rather it remains a social construct and, as such, remains subject to change particularly with advances in science and technology and a rapidly changing security context. ${ }^{71}$ This is a particular concern in light of the adoption and continued use of chemical weapons by actors involved in the Syrian conflict, a trend that has the potential to erode notions of CBW as an ideological anathema. As Guthrie has stated "There is certainly a huge risk of normalising [the use of chemical weapons] ... This latest allegation of use is another contribution to the slow and steady diminishing of the taboo."72

Moreover, there remains a risk that CBW may be perceived as more ideologically compatible amongst contemporary violent extremist groups than in the past. As a recent European Parliamentary Research Service briefing indicated "ISIL/Da'esh is considered to be particularly dangerous because of its radical ideology and its declared intention to shock: the group has used 'shock tactics' effectively to attract new recruits". ${ }^{73}$ This inclination to shock, including through the use of novel, extreme tactics, suggests CBW could potentially be compatible with the tactics of groups, such as Daesh. Moreover, significant figures such as Bin Laden, as well as certain Islamic scholars, have explicitly encouraged the adoption and use of CBW. For example Al Qaeda's flagship magazine Inspire cited religious scholars as encouraging Jihadists to "...throw on them fire, snakes or scorpions...", “... Put blood, feces or poison in their water...", and "...strike them with ... scorpions snakes and all what harms them...".

Yet whilst alarming, it is of note that Daesh have not been particularly forthcoming in claiming responsibility for the use of chemical weapons in Syria (or Iraq), although they are willing to actively promote other shocking acts. Furthermore, the justification for $\mathrm{CBW}$ is rather weak to any critical appraisal; "throwing scorpions" is a far cry from

\footnotetext{
68 A Moghadam, "How Al Qaeda Innovates" (2013) 22 Security Studies 466, available at <http://www.tandfonline. com/doi/abs/10.1080/09636412.2013.816123>.

69 G Ackerman, “Appendix III' in Rasmussen, supra, note 11.

70 RM Price, The Chemical Weapons Taboo (Cornell University Press, 1997); C Jefferson, "The Taboo of Chemical and Biological Weapons: Nature, Norms and International Law" (University of Sussex, 2009).

71 J Littlewood, "How Norms Breakdown: Can Chemical and Biological Weapons Become Accepted?" ISA conference paper (2016).

72 R Guthrie, as quoted in E Graham-Harrison, "Chemical weapons attacks in Syria may normalise war crimes, experts warn", The Guardian (11 August 2016).

73 Beatrix Immenkamp, "ISIL/Da'esh and 'Non-Conventional' Weapons of Terror" (2015), available at <http://www. europarl.europa.eu/RegData/etudes/BRIE/2015/572806/EPRS_BRI(2015)572806_EN.pdf>.
} 
weapons of mass destruction and the comments of three Imams is surely outweighed by a statement attributed to the first Caliph exhorting troops to "overcome their enemies by bravery and never by poison". ${ }^{74}$ Nevertheless, the more frequent use of low-level chemicals remains a cause of consternation because of the challenge they pose to the norm against such weapons, the visibility these events give to chemical weapons, and the potential for chemical weapons adoption to become "darkly fashionable" among extremist groups outside of Syria and Iraq.

\section{Organisational factors}

Organisational factors are important, something noted by several scholars, ${ }^{75}$ but neatly articulated by Kollars and Bristert: "decentralized organizations excel at generating new ideas, [but] they carry them out poorly. Conversely, centralized organizations can more easily coordinate attacks, but are hypothetically less innovative". 76 This argument is certainly borne-out in the context of IED innovation in Europe ${ }^{77}$ however, the role of organisational factors in CBW adoption is less clear, with some well-documented case studies, such as that of Aum Shinrikyo, suggesting innovation is possible in certain highly centralised organisations, but particularly those with a leadership with a "techno-fetishist affinity"78 towards such weapons.

Nonetheless, it remains a concern that recent exhortations from radical groups have encouraged those unable to participate in Jihad directly in countries, such as Iraq, to wage a much more disaggregated and decentralised Jihad. ${ }^{79}$ This has been achieved either through "lone wolf" attacks undertaken without any direct support ${ }^{80}$ or, more significantly, "remotely guided plots", that is "violence conceived and guided by operatives in areas controlled by the Islamic State whose only connection to the wouldbe attacker is the internet." 81 Lone wolf attacks are comparatively rare in Europe and, although they can be devastating (such as in the case of the terrorist attack by Anders Breivik, which arguably falls within the "lone wolf" category), an analysis of lone wolf attacks in Europe by Ellis et al suggests that " 76 per cent failed to cause any fatalities". 82 More common of late have been plots in which individuals have been remotely encouraged and/or guided through the internet; according to Burke, such plots include a "wave of attack[s] in France" in 2015 and a number of incidents in Germany. ${ }^{83}$

\footnotetext{
74 JP Zanders, "International Norms against Chemical and Biological Warfare: An Ambiguous Legacy" (2003) 8 Journal of Conflict and Security Law 391.

75 Horowitz, supra, note 6, 33; Rasmussen, supra, note 11.

76 NA Kollars and PD Bristert, “The Terrorists That Couldn't: Seeing Terrorist Innovation as a Risky Venture” (2014) 8 The Homeland Security Review 199.

77 Revill, supra, note 44.

78 Nehorayof, Ash and Smith, supra, note 32.

79 Dugald McConnell and Brian Todd "Al Qaeda branch calls for new attacks against United States" CNN (5 August 2015).

80 C Ellis and others, "Lone-Actor Terrorism: Final Report" (2016), available at <https://rusi.org/publication/ occasional-papers/lone-actor-terrorism-final-report>.

81 R Callimachi, "Not 'Lone Wolves' After All : How ISIS Guides World's Terror Plots From Afar" The New York Times (4 February 2017), available at <https://www.nytimes.com/2017/02/04/world/asia/isis-messaging-app-terrorplot.html?_r $=0>$.

82 Ellis and others, supra, note 80 .

83 J Burke, "The Myth of the 'lone Wolf' Terrorist" The Guardian (30 March 2017), available at <https://www. theguardian.com/news/2017/mar/30/myth-lone-wolf-terrorist $>$.
} 
Neither "lone wolves" nor the perpetrators of "remotely guided plots" in Europe have seemingly sought to use CBW and, even taking into account that these decentralised entities have excelled at generating new ideas and demonstrated the capacity to carry them out, such attacks have so far involved relatively unsophisticated weapons. As significant CBW programs will likely require a number of social commitments and external linkages to function - from supply chains to expertise - it seems significant CBW adoption appears largely incompatible, or less compatible, with either decentralised remotely guided terrorism or smaller loosely affiliated group actors. This does not, however, rule out the possibility of groups virtually sharing operationally-relevant information pertaining to low-level, scruffy CBW or indeed facilitating the delivery of precursor chemicals and equipment intended for European targets from afar. ${ }^{84}$

\section{Visibility and "Fashionability" of CBW}

A fifth factor is the visibility, and perhaps the "fashionability" of CBW. Non-state groups cannot use a weapon that they or their networks are not aware of. As the, then, Al Qaeda number two, Ayman Al Zawahiri, reportedly stated “... [Al Qaeda] only became aware of [chemical and biological weapons] when the enemy drew our attention to them by repeatedly expressing concern that they can be produced cheaply". ${ }^{85}$ In contrast, when there are visible examples of success, "Militant groups will seek to emulate tactics they deem as particularly novel, effective, and fear-inducing". ${ }^{86}$ This copy-cat-type process has been well documented with other forms of terrorist innovation ${ }^{87}$ and suggests there is potential for CBW to become somehow darkly "fashionable".

Fashionability certainly seems to have had a bearing on small-scale ricin plots, long a source of fascination amongst right-wing extremists in the US, the success of the TV series "Breaking Bad" increased the number of copycat efforts to use ricin in personal attacks, although not in a manner necessarily consistent with a wider understanding of CBW terrorism. ${ }^{88}$ Similarly anthrax hoaxes and white powder letters increased significantly following the Amerithrax attack in $2001 ;^{89}$ and, to provide some historical perspective, France endured a "wave of vitriolage" in the late 1880 s with an estimated "83 reported cases" of chemical assault through acid throwing. ${ }^{90}$

A more recent example of greater concern for contemporary European security, is the use of chemical weapons in Syria. A report titled A New Normal by the Syrian American Medical Society reports treating "victims from at least 161 chemical attacks". ${ }^{91}$ Whilst this is difficult

84 Callimachi, supra, note 81.

85 M Leitenberg, "Assessing the Biological Weapons and Bioterrorism Threat", Strategic Studies Institute (SSI) Monograph (2005).

86 Moghadam, supra, note 68.

87 Gill and others, supra, note 38.

88 S Brown, "Man Who Bought Ricin Dealt in 'death', Prosecutors Say” New York Daily News (2015); supra, note 28; S Stanton and D Walsh, "Inspired by 'Breaking Bad,' Carmichael man turned to Internet poison sales" The Sacremento Bee (2016); D Nelson, "Iowa man gets 35 years for 'Breaking Bad' ricin murder plot”, News 10 ABC (2016).

89 FBI, "FBI Warns Against Anthrax Hoaxes Recent National Press Releases" (Federal Bureau of Investigation (FBI), 2001), available at <https://archives.fbi.gov/archives/news/pressrel/press-releases/fbi-warns-against-anthrax-hoaxes $>$.

90 J Welsh, "A Comparative Exploration of Acid Attack Violence", Center for Global on International Health, Carolina Papers on International Health No 32 (2009).

91 Syrian American Medical Society, "A New Normal - Ongoing Chemical Weapons Attacks in Syria” (2016). 
to verify, the UN-OPCW Joint Investigative Mechanism (JIM) has indicated there is evidence of a small number of attacks having been carried out in Syria, the majority of which have been carried out by the Syrian Arab Armed Forces, ${ }^{92}$ but at least one is believed to have been undertaken by the Islamic State in Iraq and the Levant (ISIL). ${ }^{93}$ Similarly, French intelligence has reported five "proven" cases of sarin use "attributed to the Syrian regime", 22 cases in which they have a "strong presumption of the use of chlorine by the Syrian regime" and three incidents of "Mustard gas attack attributed to Daesh". 94 Such ongoing reports of chemical weapons use in Syria suggests that low-level chemical weapons are increasingly visible, raising the possibility of $\mathrm{CW}$ becoming more darkly fashionable as a tool of non-state actors, something potentially amplified by sensationalist media headlines.

\section{Environmental context}

A final cluster of factors is the wider environmental context, ${ }^{95}$ including the space to trial weapons; the extent of countermeasures and preparedness of target populations; and the availability of "windows of opportunity". The space to test and trial new weapons has been identified as important in Rogers' work on "trialability", that is "the degree to which an innovation may be experimented with on a limited basis". 96 Several scholars of terrorist innovation have also emphasised the importance of a "hospitable environment" as a precondition for terrorist innovation, ${ }^{97}$ with Dolnik demonstrating how safe havens provide space and time for innovation. ${ }^{98}$ This appears the case with significant historical IED campaigns, ${ }^{99}$ but also seemingly with major CBW events. For example, Aum benefited from considerable time and space (as well as resources) for their program and reportedly "attempted at least ten chemical agent and ten biological agent attacks", 100 prior to "succeeding" with sarin in Tokyo; ${ }^{101}$ whereas the Rajneeshees had several attempts at testing poisons before "successfully" contaminating salad bars with salmonella. In contrast, the crude CSA plot to contaminate water supplies was foiled, although as Carus notes, in time "CSA members might have found a more effective means of delivering cyanide if they had not been stopped by the FBI" ${ }^{102}$ It is notable in

92 OPCW/UN, "Third Report of the Organization for the Prohibition of Chemical Weapons-United Nations Joint Investigative Mechanism" (2016); and OPCW/UN, 2016. Fourth report of the Organization for the Prohibition of Chemical Weapons-United Nations Joint Investigative Mechanism.

93 Marea, Aleppo governorate, 21 August 2015. OPCW/UN, "Third Report of the Organization for the Prohibition of Chemical Weapons-United Nations Joint Investigative Mechanism” (2016) p. 14.

94 France, "Allegations of Use of Chemical Weapons in Syria since 2012" (2017), available at <http://www. diplomatie.gouv.fr/IMG/pdf/170425_-_national_evaluation_annex_-_anglais_-_final_1_cle8211fe.pdf>.

95 Kollars and Bristert, supra, note 76.

96 Rogers, supra, note 7.

97 G Ackerman, “Appendix III' in Rasmussen, supra, note 11.

98 See also Cragin, who argues that groups will seek to "test drive" a technology before committing to adopt can provide significant information and reduce adoption risks": K Cragin and others, "Sharing the Dragon's Teeth Terrorist Groups and the Exchange of New Technologies" (RAND Corporation, 2007).

99 "Kibalchich [Narodnaya Volya] tested his explosive devices in the forest along the Russian/Finnish border; the [IRA] developed bombs in secluded locations away from the border, presumably in part to be able to test devices; and Marwan Kreeshat trialled his altimeter bomb in the mountains in Germany"; Revill, supra, note 44.

100 Nehorayof, Ash and Smith, supra, note 32.

101 Danzig, supra, note 56.

102 Carus in Tucker, supra, note 25. 
this regard that the European context is not a particularly "hospitable environment" for acquiring and trialling chemical or biological weapons, with a series of EU counterterrorism projects having been undertaken to detect $\mathrm{CBW}$ and prevent the proliferation of dual-use materials. ${ }^{103}$

Second, yet related to the above, government countermeasures have been highlighted by several scholars as important drivers of "innovation as terrorists seek to circumvent new security procedures". ${ }^{104}$ In addition to which, in the case of CBW, the preparedness of target states to react and respond to CBW use may also have a bearing on the methods and targets of non-state actors, with robust emergency response systems and resilient societal fabrics potentially undermining the appeal of CBW. In this regard, it is encouraging that at the European level, response and resilience have been given considerable attention through projects, such as the EU Framework 7, "End-user driven DEmo for cbrNE" or EDEN project ${ }^{105}$ as well as the establishment of the Early Warning and Response System, and Rapid Alert System for biological and chemical incidents. ${ }^{106}$

A third element of the environmental context cluster are "windows of opportunity" to acquire and potentially use CBW with the "use of chemical weapons in conflict areas ... largely conditioned by availability and means of dissemination in the region". ${ }^{107}$ One of the reasons for the rise and rise of IEDs in Iraq circa 2006, was, in part, the convergence and availability of IED components and skills, drawing from pilfered weapons caches and locally available materials and supported by former Baathist regime expertise; but also, in part, because of the windows of opportunity for using IEDs against coalition forces and the wide range of then-accessible targets. ${ }^{108}$ The same opportunism can also be detected in some past cases of CBW adoption and use by non-state actors, for example, the Tamil Tiger's seizure of chlorine cylinders in 1990 "was opportunistic in that the chlorine was readily available and satisfied an urgent military need"; whereas AQI's chlorine augmented truck bombs also appear opportunistic. ${ }^{109}$ As Karasik, has suggested "those who use toxic weapons are also taking whatever opportunities become available". 110

The European context offers a number of possible sources of dual-use materials. However, key precursors are largely "under strict control of governments", ${ }^{111}$ and whilst

\footnotetext{
103 See European Commission, "European Civil Protection and Humanitarian Aid Operations" (EU/ECHO, 2016) $<$ http://ec.europa.eu/echo/funding-evaluations/financing-civil-protection-europe/selected-projects_en>; see also Council of the European Union, "Council Conclusions on Strengthening Chemical, Biological, Radiological and Nuclear (CBRN) Security in the European Union - an EU CBRN Action Plan" (2009).

104 Rasmussen, supra, note 11,33; Ackerman has certainly illustrated this point in relation to the development of IRA mortars as a response to the fortification of key targets: see G Ackerman, "The Provisional Irish Republican Army and the Development of Mortars" (2016) 9 Journal of Strategic Security 12, available at $<\mathrm{http} / / /$ scholarcommons.usf. edu/jss/vol9/iss1/4/> 14 .

105 Eden Consortium, "EDEN Project”, see <https://eden-security-fp7.eu/eden,id,11, about.html>.

106 European Commission, "European Commission Early Warning and Rapid Alert Systems in the Field of Health Threats" (European Commission Public Health, 2017), available at <https://ec.europa.eu/health/preparedness_response/ generic_preparedness/planning/rapid_alert_en>.

107 Supra, note 39.

108 Revill, supra, note 44.

109 JB Tucker, "The Future of Chemical Weapons" (2010) The New Atlantis 3.

110 Karasik, supra, note 46.

111 Supra, note 39.
} 
low-level chemical weapons ingredients, specifically toxic industrial chemicals (TICs), may be widespread across Europe, the barriers to acquiring such materials are likely to be relatively more robust, although not infallible. Moreover, there have also been a considerable number of national initiatives (including those intended to develop penal legislation and enforcement capacity) across Europe, and the basic legal and regulatory components are in place in most cases. It will be important to ensure that such measures are both enforced and are not solely WMD-centric, but able to deal with acts of acquisition and development which whilst pernicious, fall short of efforts to acquire weapons capable of mass destruction in humans. It will also be important to ensure that states developed the necessary investigative expertise to pursue and prosecute crimes involving chemical and biological weapons. This may require specific skill sets in order to inter alia, preserve the chain of evidence and provide robust forensic analysis, as well as mechanisms for cooperation with actors in other jurisdictions and across national borders in order to be effective. ${ }^{112}$

\section{Conclusions}

This article has argued that the adoption of CBW by non-state actors has been influenced by a number of interlinked clusters of factors, including the relative advantage, the complexity, ideological compatibility, organisational structure, visibility and environmental context. Although there are limits to detailed data on such factors in relation to a long and diverse history of past case studies, there are nonetheless some generalisable lessons that may be learned from the past which can inform the future.

First, the relative advantages to CBW lie not necessarily in simply killing, but in other utilities such as economic sabotage, the generation of media attention and prestige; incapacitation; criminal purposes; destabilisation and disruption; deterrence and denial. Certain utilities, such as sabotage, destabilisation, disruption and denial in particular, can be amplified by sensationalist press coverage which in turn can generate a disproportionate reaction. The range of utilities and potential for amplification means that CBW may appeal to a variety of different groups in the future, including Daesh, but also, potentially, white supremacist groups, environmentalist and other violent extremist movements. However, the adoption of $\mathrm{CBW}$ by such groups also has disadvantages. The consequences of CBW adoption by non-state actors, if proven, would be significant with many EU countries imposing significant custodial sentences for acquisition. If this does not serve as a deterrent, the complexity of CBW, the potential opportunity costs of pursuing CBW over other means of causing harm and the risk of alienating otherwise sympathetic constituencies through association with $\mathrm{CBW}$, might serve to dissuade.

Complexity is a major factor that is changing to some extent with advances in the life sciences and the development of enabling technologies. However, significant biological and chemical weapons remain complex and complicated - although the same cannot be said for scruffy chemical weapons. This suggests that there is a need to guard against technological surprise including the shock of the old (and the scruffy). Moreover, it is

112 Sibylle Bauer and A Wetter, "Comparing Sanctions and Prosecutions Related to Export Control Violations in the EU” (UK Quadripartite Select Committee, 2007). 
also apparent that any sense of ideological opprobrium towards chemical weapons may erode with the continued use of such weapons by state and non-state actors in Syria, in the process 'chipping away' at the norm against chemical weapons and potentially leading to such weapons becoming somehow grimly "fashionable".

Organisationally, the apparent trend towards "remotely guided plots" works against the adoption of sophisticated CBW which will likely require a more centralised development process; but not necessarily the adoption of low-level chemical weapons. Although Europe is relatively well regulated, with dual-use precursors comparatively better controlled and response systems relatively well-developed than in other parts of the world, it cannot be overlooked that lucky amateurs might be able to successfully adopt and develop CBW with significant effect, despite the odds against them and the challenges to tradecraft in Europe.

This presents a rather fuzzy risk spectrum for those seeking to prevent, prosecute and respond to $\mathrm{CBW}$ adoption across Europe. Moreover it is a risk spectrum for which neither technological quick fixes nor simple, siloed solutions can be applied. There are a number of things that have been - and are being - done to prevent such weapons being adopted and used: from softer ethical guidelines to reinforce the norm, to penal legislative measures. Yet it needs to be recognised that such measures can only reduce the risk, not eliminate it and efforts towards prevention need to be complimented with an all-hazard public health preparedness capability able to tackle a number of possible CBW-related scenarios. 